J. Dairy Sci. 95:7377-7383

http://dx.doi.org/10.3168/jds.2012-5733

(C) American Dairy Science Association ${ }^{\circledR}, 2012$.

\title{
Characterization of Staphylococcus aureus isolates in milk and the milking environment from small-scale dairy farms of São Paulo, Brazil, using pulsed-field gel electrophoresis
}

\author{
S. H. I. Lee, ${ }^{\star}$ C. H. Camargo,† J. L. Gonçalves,‡ A. G. Cruz,§ B. T. Sartori, ${ }^{\star}$ M. B. Machado, ${ }^{\star}$ \\ and C. A. F. Oliveira*1 \\ *University of São Paulo, Faculty of Animal Science and Food Engineering, Department of Food Engineering, Av. Duque de Caxias Norte, \\ 225, CEP 13635-900 Pirassununga/São Paulo, Brazil \\ †State University of São Paulo, Department of Microbiology and Immunology, 18618-970 Botucatu/São Paulo, Brazil \\ łUniversity of São Paulo, School of Veterinary Medicine and Animal Science, Department of Nutrition and Animal Production, \\ 13635-900 Pirassununga/São Paulo, Brazil \\ §State University of Campinas, Faculty of Food Engineering, Department of Food Technology, Caixa Postal 6121 CEP \\ 13083-970 Campinas/São Paulo, Brazil
}

\section{ABSTRACT}

This research aimed to evaluate the occurrence of Staphylococcus aureus isolates in milk and in the milking environment of 10 small-scale farms $(<400 \mathrm{~L} / \mathrm{d})$ located in the regions of Franca and Ribeirão Preto, state of São Paulo, Brazil. Two-hundred twenty samples of milk were collected from individual cows, along with 120 samples from bulk tank milk, 389 samples from milking equipment and utensils (teat cups, buckets, and sieves), and 120 samples from milkers' hands. Fifty-six Staph. aureus strains were isolated from 849 analyzed samples (6.6\%): 12 (5.5\%) from milk samples of individual cows, $26(21.7 \%)$ from samples of bulk tank milk, $14(3.6 \%)$ from samples collected from equipment and utensils, and $4(3.3 \%)$ from samples from milkers' hands. Pulsed-field gel electrophoresis typing of the 56 Staph. aureus isolates by $S m a$ I restriction enzyme resulted in 31 profiles (pulsotypes) arranged in 12 major clusters. Results of this study indicate a low incidence, but wide distribution of Staph. aureus strains isolated from raw milk collected from individual cows and surfaces of milkers' hands and milking equipment in the smallscale dairy farms evaluated. However, the high percentage of bulk milk samples found with Staph. aureus is of public health concern because raw, unprocessed milk is regularly consumed by the Brazilian population.

Key words: Staphylococcus aureus, environment, pulsed-field gel electrophoresis, bulk milk

Received May 15, 2012.

Accepted August 26, 2012.

${ }^{1}$ Corresponding author: carlosaf@usp.br

\section{INTRODUCTION}

Staphylococcus aureus is an important foodborne pathogen that causes several diseases transmitted between humans and animals, including infections of the mammary gland of milk-producing animals (Asperger and Zangerl, 2001). In dairy cattle, Staph. aureus is frequently associated with clinical and subclinical mastitis (Fagundes et al., 2010), which is a route for the pathogen to contaminate milk and other dairy products (Jørgensen et al., 2005). Staphylococcus aureus produces several virulence factors, including enterotoxins and toxic shock syndrome toxin (TSST-1; Asperger and Zangerl, 2001). Although pasteurization kills Staph. aureus cells, thermostable enterotoxins generally retain their biological activity in pasteurized milk and dairy products (Roberson et al., 1994). A large number staphylococcal food poisoning (SFP) cases have been reported worldwide (Rosec et al., 1997; Akineden et al., 2001; Rizek et al., 2011). Although in Brazil the exact number of SFP outbreaks is unknown, previous studies indicated that raw milk and dairy products manufactured from raw milk play important roles in SFP outbreaks in humans (Gilmour and Harvey, 1990; Tondo et al., 2000), which reinforces that contamination of milk by Staph. aureus is a public health problem (Cardoso et al. 1999; Fagundes and Oliveira, 2004; Oliveira et al., 2011).

Staphylococcus spp. may be found on skin and mucous membranes of healthy warm-blooded animals, as well as in soil, air, and water (Asperger and Zangerl, 2001). This pathogen easily spreads in the environment, requiring careful procedures during milking and sanitization to avoid the transmission among cows, equipment, and utensils (Akineden et al., 2001). Human-to-bovine transmission of Staph. aureus has been demonstrated by molecular studies that have shown 
that similar strains may be isolated from handlers and the milk of cows with mastitis (Jørgensen et al., 2005). Human handlers, milking equipment, the environment, and the udder and teat skin of dairy animals are possible sources of bulk milk contamination (André et al., 2008; Dufour et al., 2012). However, differences in management systems and factors such as the presence of flies capable of transmitting Staph. aureus may account for the observed variation in its prevalence as mastitiscausing agent (De Vliegher et al., 2012).

The incidence of Staph. aureus as a mastitis-causing agent in Brazilian dairy farms is generally high, ranging from 17 to $50 \%$ (Lange et al., 1999; da Silva et al., 2003; Fagundes et al., 2010), based on the diagnostic of individual cows in each farm. However, little is known about the occurrence of Staph. aureus in raw, refrigerated milk on dairy farms, and about the main sources of contamination on the farms, especially in small-scale production, which contributes with almost $30 \%$ of the total milk produced in Brazil. Small-scale farms generally sell the raw milk to dairy factories, which ultimately may contribute to the bacterial load of bulk tank milk in the industry. Moreover, these farms also sell raw milk directly to the public; although this practice is prohibited, informal milk in Brazil is almost $20 \%$ of the total milk produced in the country. Despite these facts, investigations on the epidemiology of important pathogens and actions aiming to improve the microbiological quality of milk in dairy farms have been addressed mostly in medium and large commercial operations. Improvement and monitoring of raw milk quality is a major issue for the development of the milk production chain worldwide (Oliveira et al., 2011). In this context, this study aimed to investigate the occurrence of Staph. aureus in milk and the milking environment of dairy farms in the state of São Paulo, Brazil.

\section{MATERIALS AND METHODS}

\section{Sampling}

The study was conducted on 10 dairy farms with a mean daily output of up to $400 \mathrm{~L}$ of milk: 5 (A to E) located in the region of Franca and 5 ( $\mathrm{F}$ to $\mathrm{J}$ ) in the region of Ribeirão Preto (state of São Paulo, Brazil) from August 2010 to January 2011. The dairy farms were commercial operations, and represented a convenience sampling, with the purpose of getting a gross estimate of results related to a research subject (Carrillo et al., 2012). In the present study, dairy farms were randomly selected by drawing among members of a dairy cooperative located in those 2 regions, which are important milk regions in São Paulo.
Individual milk samples were obtained from at least 5 cows from each dairy farm and were collected aseptically, directly from all quarters. At the end of the milking procedure, duplicate bulk tank milk samples $(500 \mathrm{~mL})$ were also collected in sterile milk containers. Samples from the milking equipment (internal surfaces of teat cups), utensils (sieves and buckets), and hands of milkers in each farm were also collected with sterile dry swabs (Pro-Lab Diagnostics, Round Rock, TX), previously wet and stored in peptone water, according to da Silva et al. (2003). Sampling procedures were performed after the cleaning process of milking equipment and utensils, and before the sanitization step. Swab samples of milkers' hands were collected during the milking procedure. Samples were collected once per month for 6 mo, totaling 220 samples of milk from individual cows, 120 samples of bulk tank milk, 120 samples from milkers' hands, and 389 samples from milking equipment and utensils. Samples were transported to the laboratory in coolers with ice $\left(5.0 \pm 1.2^{\circ} \mathrm{C}\right)$, and analyzed on the same day.

\section{Staphylococcus aureus Count and Molecular Analysis}

Isolation and identification of Staph. aureus were performed according to the Compendium of Methods for the Microbiological Examination of Foods (Lancette and Bennett, 2001). Serial dilutions of 2 replicates of each sample were plated onto Baird Parker agar (Oxoid Ltd., Hampshire, UK) supplemented with egg yolk and tellurite emulsion (1\%; Oxoid Ltd.), and incubated at $35^{\circ} \mathrm{C}$ for $48 \mathrm{~h}$. Colonies suggestive of Staph. aureus were submitted to the following tests: Gram staining, catalase reaction, clotting of rabbit plasma, presence of clumping factor (Staphyclin test; Laborclin, Pinhais, Brazil), and acetoin production. Suggestive colonies were gray to black (potassium tellurite reaction) surrounded by clear zones (egg yolk reaction; Capurro et al., 1999).

All Staph. aureus strains were subjected to chromosomal DNA and restriction endonuclease digestion strictly following the procedures as described by McDougal et al. (2003). Pulsed-field gel electrophoresis (PFGE) was run using a CHEF-DR III system (BioRad Laboratories Inc., Hercules, CA). Running parameters were as follows: $200 \mathrm{~V}(6 \mathrm{~V} / \mathrm{cm})$; temperature, $14^{\circ} \mathrm{C}$; initial switch, $5 \mathrm{~s}$; final switch, $40 \mathrm{~s}$; and length, $19 \mathrm{~h}$. After the electrophoresis run was completed, the gel was stained with $50 \mu \mathrm{L}$ of ethidium bromide solution $(10 \mathrm{mg} / \mathrm{mL}$; Sigma-Aldrich, St. Louis, MO) in 500 $\mathrm{mL}$ of distilled water for $20 \mathrm{~min}$ in a covered container, and destained in $500 \mathrm{~mL}$ of fresh distilled water for 30 
Table 1. Incidence of Staphylococcus aureus in small-scale dairy farms from Franca and Ribeirão Preto, São Paulo, Brazil

\begin{tabular}{|c|c|c|c|}
\hline Sampling site & \multicolumn{3}{|c|}{ No. of positive samples/total no. of samples tested (\%) } \\
\hline Milkers' hands & $0 / 60(0)$ & $4 / 60(6.7)$ & $4 / 120(3.3)$ \\
\hline \multicolumn{4}{|l|}{ Raw milk } \\
\hline Individual cows & $3 / 52(5.8)$ & $9 / 168(5.4)$ & $12 / 220(5.5)$ \\
\hline Bulk tanks & $9 / 60(15.0)$ & $17 / 60(28.3)$ & $26 / 120(21.7)$ \\
\hline
\end{tabular}

${ }^{1}$ Surfaces of milking machine (internal surface of teat cups) and utensils (sieves and buckets). No differences $(P>0.05)$ existed between the percentages within the row.

min. Gel Doc XR (Bio-Rad Laboratories Inc.) was used to capture the images under UV light. A molecular weight marker (Lambda Ladder PFG Marker; BioLabs, São Paulo, Brazil) was used in the analysis, with an effective range from 48.5 to $727.5 \mathrm{~kb}$ (PFGE). Bands above or below were not included in the analysis.

Isolates of Staph. aureus were placed in groups of identical or related strains by comparing banding patterns by computer analysis (BioNumerics, version 6.1; Applied Maths Inc., Austin, TX). Banding patterns were marked using several different stained gel images, in addition to curves provided by BioNumerics. A known strain of Staph. aureus (N315) was included in the macrorestriction analysis by PFGE; therefore, this strain could work as a control for the efficiency of the SmaI restriction enzyme. A dendrogram was generated by the unweighted pair group method with arithmetic mean (UPGMA), and Dice coefficients were used to define the groups based on $80 \%$ similarity (McDougal et al., 2003).

\section{Statistical Analysis}

The chi-squared test was used to compare the frequency of samples positive for Staph. aureus in the 2 regions studied (Franca and Ribeirão Preto), using $\alpha=$ 0.05 (Gacula and Singh, 1984).

\section{RESULTS}

\section{Incidence of Staph. aureus}

The incidence of Staph. aureus on dairy farms of the state of São Paulo is shown in Table 1. Among all samples of the milk of individual cows, bulk tank milk, swabs from milking equipment, and milkers' hands (n $=849), 56(6.6 \%)$ Staph. aureus strains were isolated. Dairy farms from the Franca region (dairy farms A to E) showed $18(5.3 \%)$ positive samples, whereas dairy farms from Ribeirão Preto (F to J) showed 38 ( $7.5 \%)$ positive samples. No differences $(P>0.05)$ existed between the percentages of positive samples for Staph. aureus in dairy farms located in the Franca or Ribeirão Preto regions, except for raw milk samples collected from bulk tanks, which showed a tendency to higher percentages $(P=0.076)$ in samples from Ribeirão Preto farms $(28.3 \% ; \mathrm{n}=17)$.

\section{Molecular Characterization by PFGE}

Molecular characterization of Staph. aureus strains by PFGE is shown in Figure 1. The SmaI macrorestriction fragment profiles of 56 Staph. aureus isolates showed great genetic diversity among the strains isolated from different samples from the same farm, and from different farms throughout the sampling period. Thirtyone profiles could be defined, from all Staph. aureus strains typed, with $80 \%$ similarity, and the dendrogram revealed 12 major clusters of isolates.

The genotype clusters of isolates by sample source are presented in Table 2. Seven clusters (A, B, E, F, $\mathrm{G}, \mathrm{K}$, and $\mathrm{L}$ ) were isolated only from different sites in dairy farms from Ribeirão Preto, whereas 3 clusters $(\mathrm{D}, \mathrm{I}$, and $\mathrm{J}$ ) were from samples of milk collected in farms from Franca. However, a large number of different strains were found in cluster $\mathrm{C}$ and 2 strains in cluster $\mathrm{H}$ isolated from different regions and points of sampling. In particular, cluster $\mathrm{C}$ strains were found in raw milk from individual cows and bulk tank in dairy farms from the Ribeirão Preto and Franca regions, and at different times of sample collection.

\section{DISCUSSION}

The incidences of Staph. aureus isolates in swab samples from milkers' hands, milking equipment, samples of raw milk from individual cows, and bulk tanks were $3.3 \%(\mathrm{n}=120), 3.6 \%(\mathrm{n}=389), 5.5 \%(\mathrm{n}=220)$, and $21.7 \%(\mathrm{n}=120)$, respectively. Higher results were reported by D'Amico and Donnelly (2010) in raw milk 


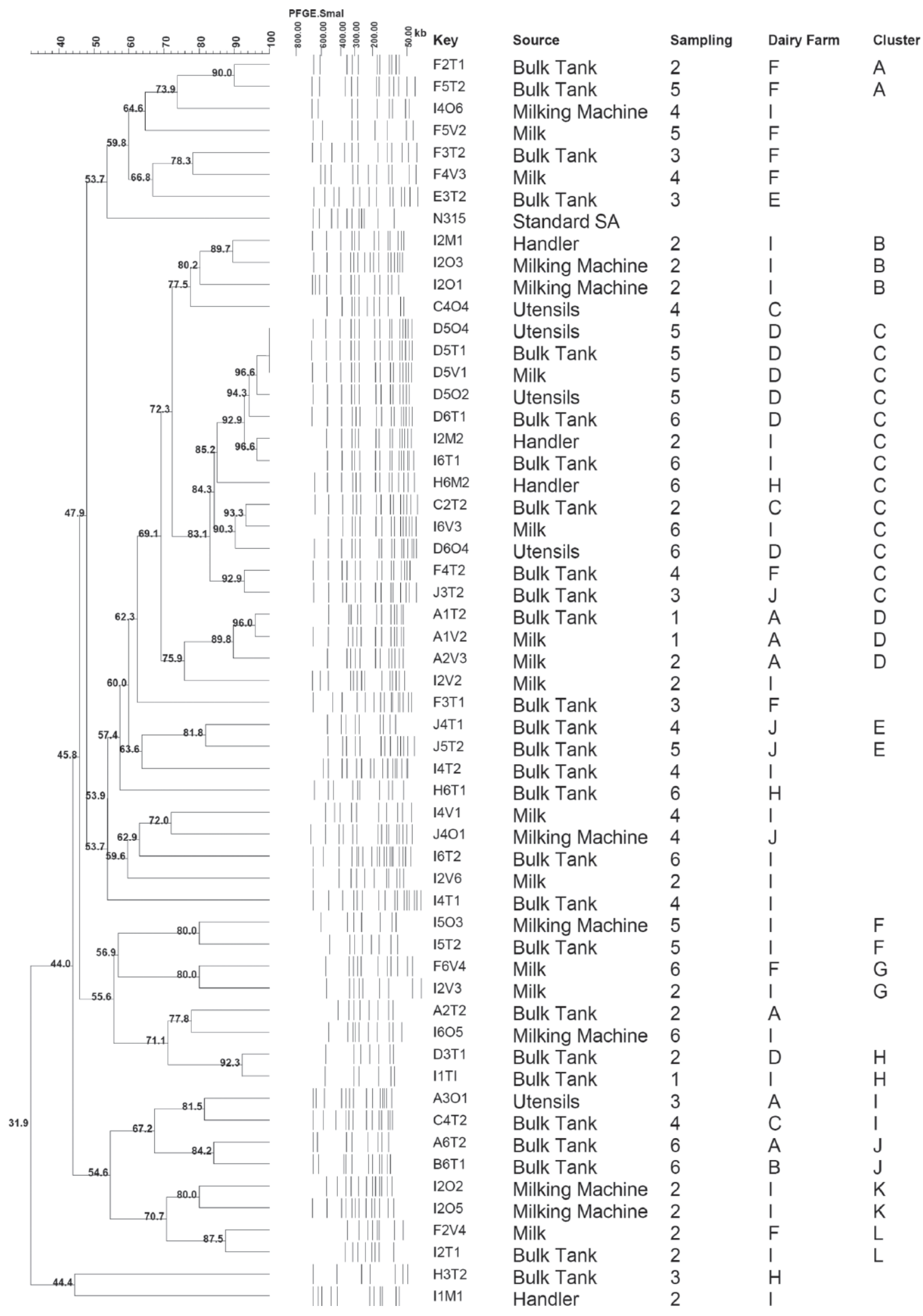

Figure 1. Dendrogram showing SmaI restriction enzyme pulsed-field gel electrophoresis (PFGE) patterns of genomic DNA of Staphylococcus aureus isolated from the milking environment (Standard SA = Staph. aureus N315). Isolates were cluster generated based on an $80 \%$ Dice similarity cutoff value of the unweighted pair group method with arithmetic mean (UPGMA) clustering method (0.5\% optimization; $1.25 \%$ tolerance). 
Table 2. Staphylococcus aureus genotype clusters (A-L) by sample source in small-scale dairy farms from Franca (F) and Ribeirão Preto (RP), São Paulo, Brazil

\begin{tabular}{|c|c|c|c|c|c|c|c|c|}
\hline \multirow{3}{*}{$\begin{array}{l}\text { Staph. aureus } \\
\text { cluster }\end{array}$} & \multirow{2}{*}{\multicolumn{2}{|c|}{$\begin{array}{l}\text { Milkers' } \\
\text { hands }\end{array}$}} & \multirow{2}{*}{\multicolumn{2}{|c|}{$\begin{array}{c}\text { Milking } \\
\text { equipment }\end{array}$}} & \multicolumn{4}{|c|}{ Raw milk } \\
\hline & & & & & \multicolumn{2}{|c|}{ Individual cows } & \multicolumn{2}{|c|}{ Bulk tanks } \\
\hline & $\mathrm{F}$ & $\mathrm{RP}$ & $\mathrm{F}$ & $\mathrm{RP}$ & $\mathrm{F}$ & $\mathrm{RP}$ & $\mathrm{F}$ & $\mathrm{RP}$ \\
\hline $\mathrm{A}$ & & & & & & & & 2 \\
\hline B & & 1 & & 2 & & & & \\
\hline $\mathrm{C}$ & & 2 & 3 & & 1 & 1 & 3 & 3 \\
\hline D & & & & & 2 & & 1 & \\
\hline $\mathrm{E}$ & & & & & & & & 2 \\
\hline $\mathrm{F}$ & & & & 1 & & & & 1 \\
\hline $\mathrm{G}$ & & & & & & 2 & & \\
\hline $\mathrm{H}$ & & & & & & & 1 & 1 \\
\hline I & & & 1 & & & & 1 & \\
\hline $\mathrm{J}$ & & & & & & & 2 & \\
\hline K & & & & 2 & & & & \\
\hline $\mathrm{L}$ & & & & & & 1 & & 1 \\
\hline Total & 0 & 3 & 4 & 5 & 3 & 4 & 8 & 10 \\
\hline
\end{tabular}

samples used for small-scale artisan cheese production in Vermont in the United States. Those authors performed repeated sampling of farms over a seasonal time frame and found that 14 farms $(67 \%)$ were positive for this pathogen, which was detected in $38 \%$ of samples at an average level of $20 \mathrm{cfu} / \mathrm{mL}$. Similarly, Staph. aureus was also detected in $33(66 \%)$ of small- and medium-scale dairy farms in the northeastern region of Brazil, with this incidence being associated with the premilking teat wash procedure and postmilking teat dip (Oliveira et al., 2011). These findings are related to different levels of adoption of good practices at raw milk handling. Indeed, a comparison of the results of the present study and those reported by other authors is difficult, because the occurrence of Staph. aureus as a causative agent of subclinical mastitis varies according to the area, animal management practices, and hygiene conditions during milking, among other factors (Fagundes et al., 2010). The low percentage of Staph. aureus observed in the milk of individual cows may also be a consequence of the recent Brazilian investments in dairy cattle management that aimed at improving the microbiological quality of milk. However, from the 120 samples of bulk milk analyzed in our study, 26 (21.6\%) were positive for Staph. aureus, hence indicating a potential route of SFP transmission to consumers via contaminated milk. This would be particularly important in small-scale farms from Ribeirão Preto, where the incidence of Staph. aureus in bulk milk was higher, although the isolates were not screened in the present study for toxin genes or enterotoxin production.

Pulsed-field gel electrophoresis typing of 56 Staph. aureus isolates by $S m a \mathrm{I}$ restriction enzyme resulted in 31 pulsotypes arranged in 12 major clusters. Similar strains (clusters $\mathrm{C}$ and $\mathrm{H}$ ) were found in farms from both regions of Franca and Ribeirão Preto, which had no direct link between them, indicating the possibility of wide dissemination of some strains over vast geographic areas. In a similar study carried out in a different environment (a dairy plant in the state of Goiás, Brazil), André et al. (2008) also found high diversity among the strains, demonstrating lack of predominance of an endemic clone of Staph. aureus in the environment. Similar findings were reported in Sweden, with Staph. aureus isolates with genotypes indistinguishable from those found in milk also dominated in extramammary sites within the dairy herds studied (Capurro et al., 2010). Data presented in the current study and previous works indicate a huge variety of Staph. aureus strains either on dairy farms or in dairy plant environments, which makes the identification of a more precise relationship of multiple routes of contamination of milk difficult.

The large number of patterns observed in the present study indicated that great genetic heterogeneity among Staph. aureus strains isolated from raw milk in the farms studied. High variability in genotypic patterns may be due the diversity of locations in which Staph. aureus may be found. Similar results were found in a dairy plant in the south of Brazil, where 19 unrelated strains of Staph. aureus were isolated from raw milk (Tondo et al., 2000). To control the spread of staphylococcal infections, the sources of contamination and mechanisms of transmission must be identified. Jørgensen et al. (2005) indicated that Staph. aureus from udders may contaminate bulk milk and, subsequently, raw milk products. Association between dairy cows and their handlers, in addition poor sanitary practice, may result in the inter- 
change of staphylococcal strains and contribute to the poor microbiological quality of the milk (Adesiyun et al., 1998), which could be observed in cluster C. In the present study, PFGE was used as a tool for identifying the diversity of Staph. aureus strains among different sites inside the dairy farms, and how they contribute to contamination of the bulk milk. Although PFGE would be useful to screen for staphylococci in milk, it remains to be determined if the cost-benefit relationship of such technique would be appropriate for dairy operations in Brazil.

In the present study, Staph. aureus isolates from milkers, utensils, milk from individual cows, and bulk tank milk were epidemiologically related, indicating that it may not only be transmitted between cows on the same farm, but also disseminated among farms and different, unrelated regions. Pulsed-field gel electrophoresis identification of clusters and pulsotypes at different periods of sampling may show the persistence of the strain in the environment. However, further studies are needed to confirm this hypothesis, as it possible that the Staph. aureus strains isolated were just common strains present in the environments evaluated.

Pasteurization of milk intended for human consumption is mandatory in dairy factories in Brazil. However, improper refrigeration of raw milk in farms and transportation still exists all over the country and this problem allows the growth of pathogens such as Staph. aureus and the production of thermostable enterotoxins prior to pasteurization of raw milk. The variability of Staph. aureus strains found in samples of raw milk and surfaces stresses the need for stringent control strategies, including regular monitoring of the sanitizing procedures, to prevent the dispersion of Staph. aureus into the milking environment of smallscale dairy farms.

\section{CONCLUSIONS}

Our findings indicate a high incidence of Staph. aureus strains in raw milk from bulk tanks, and a low incidence in raw milk collected from individual cows and the surfaces of milkers' hands and milking equipment on small-scale dairy farms in the state of São Paulo, Brazil. Pulsed-field gel electrophoresis analysis showed high diversity among the strains of Staph. aureus isolated from raw milk and the milking environment. The fact that a large percentage of bulk milk samples tested positive for Staph. aureus is of public health concern because unprocessed milk is regularly consumed by the Brazilian population because of cultural habits and lack of information on health issues.

\section{ACKNOWLEDGMENTS}

The authors are grateful to The State of São Paulo Research Foundation (FAPESP, São Paulo, Brazil) for the financial support (grant 2009/12301-0).

\section{REFERENCES}

Adesiyun, A. A., L. A. Webb, and H. T. Romain. 1998. Prevalence and characteristics of Staphylococcus aureus strains isolates from bulk and composite milk and cattle handlers. J. Food Prot. 61:629632 .

Akineden, Ö.. C. Annemüller, A. A. Hassan, C. Lämmler, W. Wolter, and M. Zschöck. 2001. Toxin genes and other characteristics of Staphylococcus aureus isolates from milk of cows with mastitis. Clin. Diagn. Lab. Immunol. 8:959-964.

André, M. C. D. P. B., M. R. H. Campos, L. J. Borges, A. Kipnis, F. C. Pimenta, and Á. B. Serafini. 2008. Comparison of Staphylococcus aureus isolates from food handlers, raw bovine milk and Minas Frescal cheese by antibiogram and pulsed-field gel electrophoresis following SmaI digestion. Food Contr. 19:200-207.

Asperger, H., and P. Zangerl. 2001. Staphylococcus aureus. Pages 2563-2569 in Encyclopedia of Dairy Sciences. Vol. 4. H. Roginski, J. W. Fuquay, and P. F. Fox, ed. Academic Press and Elsevier Science, London, UK.

Capurro, A., A. Aspán, H. Ericsson Unnerstad, K. Persson Waller, and K. Artursson. 2010. Identification of potential sources of Staphylococcus aureus in herds with mastitis problems. J. Dairy Sci. 93:180-191.

Capurro, A., C. Concha, L. Nilsson, and K. Ostensson. 1999. Identification of coagulase-positive staphylococci isolated from bovine milk. Acta Vet. Scand. 40:315-321.

Cardoso, H. F. T., N. Silva, M. J. Sena, and L. S. Carmo. 1999. Production of enterotoxins and toxic shock syndrome toxin by Staphylococcus aureus isolated from bovine mastitis in Brazil. Lett. Appl. Microbiol. 29:347-349.

Carrillo, E., P. Varela, and S. Fiszman. 2012. Influence of nutritional knowledge on the use and interpretation of Spanish nutritional food labels. J. Food Sci. 77:H1-H8.

D'Amico, D. J., and C. W. Donnelly. 2010. Microbiological quality of raw milk used for small-scale artisan cheese production in Vermont: Effect of farm characteristics and practices. J. Dairy Sci 93:134-147.

da Silva, W. P., M. T. Destro, M. Landgraf, and B. D. G. M. Franco. 2003. Biochemical characteristics of typical and atypical Staphylococcus aureus in mastitic milk and environmental samples of Brazilian dairy farms. Braz. J. Microbiol. 31:103-106.

De Vliegher, S., L. K. Fox, S. Piepers, S. McDougall, and H. W. Barkema. 2012. Invited review: Mastitis in dairy heifers: Nature of the disease, potential impact, prevention, and control. J. Dairy Sci 95:1025-1040.

Dufour, S., I. R. Dohoo, H. W. Barkema, L. DesCôteaux, T. J. DeVries, K. K. Reyher, J.-P. Roy, and D. T. Scholl. 2012. Manageable risk factors associated with the lactational incidence, elimination, and prevalence of Staphylococcus aureus intramammary infections in dairy cows. J. Dairy Sci. 95:1283-1300.

Fagundes, H., L. Barchesi, A. Nader Filho, L. M. Ferreira, and C. A. F. Oliveira. 2010. Occurrence of Staphylococcus aureus in raw milk produced in dairy milk produced in dairy farms in São Paulo state, Brazil. Braz. J. Microbiol. 41:376-380.

Fagundes, H., and C. A. F. Oliveira. 2004. Infecções intramamárias causadas por Staphylococcus aureus e suas implicações em saúde pública. Ciência Rural 34:1315-1320.

Gacula, M. C., Jr., and J. Singh. 1984. Statistical Methods in Food and Consumer Research. Academic Press, London, UK.

Gilmour, A., and J. Harvey. 1990. Staphylococci in milk and milk products. J. Appl. Bacteriol. 69(Suppl. S19):147S-166S 
Jørgensen, H. J., T. Mørk, H. R. Høgåsen, and L. M. Rørvik. 2005. Enterotoxigenic Staphylococcus aureus in bulk milk in Norway. J. Appl. Microbiol. 99:158-166.

Lancette, G. A., and R. W. Bennett. 2001. Staphylococcus aureus and staphylococcal enterotoxins. Pages 387-403 in Compendium of Methods for the Microbiological Examination of Foods. F. P. Downes and K. Ito, ed. Am. Public Health Assoc., Washington, DC.

Lange, C., M. Cardoso, D. Senczec, and S. Schwarz. 1999. Molecular subtyping of Staphylococcus aureus isolates from cases of bovine mastitis in Brazil. Vet. Microbiol. 67:127-141.

McDougal, L. K., C. D. Steward, G. E. Killgore, J. M. Chaitram, S. K. McAllister, and F. C. Tenover. 2003. Pulsed-field gel electrophoresis typing of oxacillin-resistant Staphylococcus aureus isolates from the United States: Establishing a national database. J. Clin. Microbiol. 41:5113-5120.

Oliveira, C. J. B., W. D. Lopes Júnior, R. C. R. E. Queiroga, P. E. N. Givisiez, O. S. Azevedo, W. E. Pereira, and W. A. Gebreyes. 2011.
Risk factors associated with selected indicators of milk quality in semiarid northeastern Brazil. J. Dairy Sci. 94:3166-3175.

Rizek, C. F., M. H. Matté, M. Dropa, E. M. Mamizuka, L. M. de Almeida, N. Lincopan, G. R. Matté, and P. L. M. Germano. 2011. Identification of Staphylococcus aureus carrying the mecA gene in ready-to-eat food products sold in Brazil. Foodborne Pathog. Dis. 8:561-563.

Roberson, J. R., L. K. Fox, D. D. Hancock, J. M. Gay, and T. E. Besser. 1994. Ecology of Staphylococcus aureus isolated from various sites on dairy farms. J. Dairy Sci. 77:3354-3364.

Rosec, J. P., J. P. Guiraud, C. Dalet, and N. Richard. 1997. Enterotoxin production by staphylococci isolated from foods in France. Int. J. Food Microbiol. 35:213-221.

Tondo, E. C., M. C. Guimarães, J. A. Henriques, and M. A. Ayub. 2000. Assessing and analysing contamination of a dairy products processing plant by Staphylococcus aureus using antibiotic resistance and PFGE. Can. J. Microbiol. 46:1108-1114. 